\title{
Wolfram von Eschenbach's Parzival: Searching for the Grail
}

Wolfram von Eschenbach's German Grail romance Parzival, written in the first and perhaps early second decade of the thirteenth century, comprises almost 25,000 verses in couplets. Following the structures of initials to be found in some of the oldest manuscripts, Karl Lachmann, the first modern editor of Parzival, divided the text into units of thirty verses, and - on a higher level - into sixteen books. A reference point for dating the poem can be found in the seventh book, with an allusion made to the vineyards of Erfurt being destroyed during a war between the Staufer Philip of Swabia and the Landgrave of Thuringia, Herman I, in 1203 (379:18-20; the consequences of crop shortfall may have lasted for up to a decade, hence this period of time could reasonably have separated the remark from the actual historical event: Mertens 2004, 243). In the rich manuscript tradition of the text, which contains over eighty witnesses dating from the thirteenth to the fifteenth century, four distinct redactions of Wolfram's Parzival can be discerned, all of which originate from the thirteenth century: ${ }^{\star} \mathrm{D},{ }^{\star} \mathrm{m},{ }^{\star} \mathrm{G},{ }^{\star} \mathrm{T}$, of which ${ }^{\star} \mathrm{D}$ and ${ }^{\star} \mathrm{m}$ on the one hand, and ${ }^{\star} \mathrm{G}$ and ${ }^{\star} \mathrm{T}$ on the other, are more closely related (Stolz 2014, 457-459; variants of ${ }^{\star} \mathrm{D}$ and ${ }^{\star} \mathrm{G}$ are documented in the critical edition by Schirok (Wolfram von Eschenbach 2003) following Lachmann, while those of ${ }^{\star} \mathrm{D},{ }^{\star} \mathrm{m}$ and ${ }^{\star} \mathrm{G},{ }^{\star} \mathrm{T}$ are detailed in the electronic edition of the Parzival-Project, University of Bern). ${ }^{1}$ Besides Parzival, Wolfram left a fragmentary side story of this novel, commonly referred to as Titurel and composed in stanzas, as well as another epic text belonging to the genre of chanson de geste called Willehalm, and some love poetry, especially dawn songs (Tagelieder).

1 For the complete list of manuscript sigla, see Stolz (2016b, 381).

Note: This article is indebted to the extensive research literature on Wolfram's Grail romance gathered in Nellmann (1994), Bumke (2004), Mertens (2003 and 2011/14). The primary texts are quoted after the editions of Chrétien's Roman de Perceval provided by Busby (Chrétien de Troyes 1993), and of Wolfram's Parzival provided by Lachmann/Schirok (Wolfram von Eschenbach 2003). Concerning the latter, I have consulted, and occasionally adapted with respect to the original Middle High German text and to the specific contexts in this article, the English translations by Hatto (1980) and Edwards (2004). I wish to thank Matthias Berger (Bern) and Christoph Pretzer (Cambridge) for revising this article linguistically.

Michael Stolz (University of Bern) 


\section{Precursors: Chrétien's Roman de Perceval ou le Conte du Graal and others}

Wolfram's main source for the Parzival is Chrétien de Troyes who, with his unfinished Old French Roman de Perceval ou le Conte du Graal (c. 1180-1190), introduced the motif of the Grail into Arthurian romance and therefore into European literature. Any primitive versions of the Grail story, which Chrétien may have known from oral Breton narrators, remain unknown. Concerning this matter, origins in Indo-European or Celtic contexts have been discussed, but these are hypothetical in many respects. Central components of the Grail story such as the unanswered question, the lance and the Grail itself may indeed have occurred in Celtic tales. But the written records in which these accounts are transmitted reveal the influence of later traditions represented by Chrétien's Roman de Perceval. Prototypes of the Grail topic can be traced in archaic Irish tales like the Baile in scáil and in the Cymric genre of Mabinogion [narratives of young heroes] with the story of Peredur, contained in manuscripts from the fourteenth century (see Morgans, supra). In both the Irish and the Cymric precursors, a precious vessel or dish is bound to the solemn transfer of sovereignty within a ruling family. Allowing for all the caveats inherent in any such reconstruction, the narrative pattern predating Chrétien might have looked as follows: an infant king grows up outside society and is put to initiatory tests. He encounters his uncle and is confronted with a symbolic task related to a vessel and a lance, both covered with blood. The task is associated with a question or riddle and - especially in the Peredur-tradition - with a wrong done to the family. The infant avenges this wrong and becomes king (Mertens 2003, 24; Mertens 2011/2014, 274-275).

\section{The Graal}

In Chrétien's Roman de Perceval, the magic vessel is called a graal (1. 3220), probably after the Latin word gradale for a big flat dish in which food is arranged in stages or "grades" (Mertens 2003, 35; Mertens 2011/2014, 266). ${ }^{2}$ The word will reappear in Wolfram's Parzival as a proper name: "ein dinc, daz hiez der Grâl" (235:23, similarly 454:21) [a thing called the Grail] (see also Stolz 2010; Stolz

2 Other derivations from Latin crater [mixing vessel], or cratis [netting], as well as an occurrence of the expression graalz in Helinand of Froidmont's Chronicon are discussed by Bumke (2004, 235). 
2016a, 270-274). But whereas Chrétien's Graal is a plate apparently large enough to be filled with fish (ll. 6420-6421), Wolfram's Grâl is a precious stone endowed with magic powers. As Chrétien states in the prologue, Count Philip of Flanders commissioned his Conte du Graal (1. 13). Philip died on the third crusade in 1191, which may have led Chrétien to abandon his work; Philip's father, on his return from the second crusade in 1150, had brought to Flanders a relic of some drops of Christ's blood assumed to have been collected by Joseph of Arimathea. This sort of relic adoration evident in the patron's family may also have influenced Chrétien's concept of the Grail (Mertens 2003, 26-27; Mertens 2011/2014, 264, 267-269). In this context, it is also worth mentioning a narrative variation outside Arthurian romance to demonstrate the diversity of the Grail topic around the year 1200.

\section{Robert de Boron's Estoire dou Graal}

In that time, Robert de Boron wrote his French Estoire dou Graal for Gautier de Montbéliard who, for his part, took the cross in 1199 (Mertens 2003, 83-103; Mertens 2011/2014, 276-278). Robert seems to have planned a cycle of three parts, of which it appears he was only able to finish the first one, called Joseph d'Arimathie. In this text, the Grail appears as a relic elevated over all other cult objects related to the Passion of Christ, such as the Veil of Veronica. It is the chalice used by Jesus Christ in the ceremony of the Last Supper and used in turn by Joseph of Arimathea to collect Christ's blood during his martyrdom. Due to its sacred context, the Grail is attributed grace-giving powers; it is conceived as the centre of a religious community with almost ecclesiastical status. Joseph, who was a member of the Jewish nobility, provides a model for Christian knighthood. Besides this, Robert furnishes the Grail with a sort of salvific history: after the dispersion of the Jews, Joseph of Arimathea leaves Palestine together with his sister and his brother-in-law, Bron (Hebron). Joseph inaugurates a table similar to that of the Last Supper (and evoking that of King Arthur) for celebrating a ceremony centred on the chalice and a meal of fish, the symbol of Christ; as the fish has been caught by Bron, the latter is called the "rich fisherman". The Graal is meant to be pleasant (agreer) to a community of the righteous who participate in the ceremony. An angel tells Joseph that after him, Bron will be the custodian of the Grail; Bron is to go to the West to attend the "third man", his grandson. In a later continuation of Robert's text (the so-called Didot-Perceval), this grandson is identified as Perceval. The genealogical concept of the subsequent custodies held by Joseph, Bron and the "third man" - somewhat similar to the three Ages of the Father, the Son and the Holy Spirit in Joachim of Fiore's contemporaneous 
doctrine - stakes a claim to historical truth. Accordingly, Robert calls his text an estoire, and not a roman as had his contemporary, Chrétien de Troyes, called his Conte du Graal.

Robert's Joseph d'Arimathie contains a Grail story that goes without the figure of Perceval (whose identification as the "third man" is part of a later version influenced by Chrétien). Whether Robert's text predates Chrétien's is not verified. However, both authors introduce the word "Graal” to refer to a magic vessel used in a cultish meal; and both describe a dynasty having a "rich fisherman" as its member (Bumke 2004, 235-236). In Chrétien's Conte du Graal, this fisherman is Perceval's cousin; in Wolfram's version he will be Parzival's uncle. However, in contrast to Robert of Boron, Chrétien and Wolfram both abstain from any explicit correlation of the Grail with the Passion of Christ.

\section{Wolfram's Grail Story}

In what follows, Wolfram's treatment of the Grail story will be discussed together with Chrétien's, but with a greater focus on Wolfram's perspective (based on Johnson 1999; Mertens 2003, 25-82; Bumke 2004, 54-124, 237-239; Mertens 2011/2014, 264-269, 279-283). Differences are emphasized, where relevant, while evidence of the manuscript tradition is included where it helps to understand the idiosyncrasy of the German poem. In light of Chrétien's unfinished text and Wolfram's narrative art, the German Parzival can arguably be called the most accomplished Arthurian Grail romance (cf. Kragl, supra). Wolfram not only completes his French source but also enriches it in many ways: he devises side stories as well as the profiles of numerous characters (who, in contrast to Chrétien's appellatives, bear individual names); he establishes a complex network of family relationships and enlarges Chrétien's Arthurian world with the realm of the Orient - which is also relevant, clearly, to the Grail. As an informant surpassing his deficient source, Wolfram introduces the enigmatic figure of Kyot, who, unlike Chrétien, has supposedly offered the authentic tale to the narrator (epilogue, 827:1-4). In all likelihood, this Kyot is a fictitious reference, used to cover Wolfram's own narrative inventions for information not provided by Chrétien. By means of this arrangement, narration itself proves to be one of the most prominent features of, and even a topic to be treated in, Wolfram's Grail romance (Bumke 2004, 215-232).

A peculiarity of Wolfram's narrative is the fact that the mysteries of the Grail are only gradually disclosed. This principle corresponds to the personality of the protagonist: Parzival is characterized as a foolish youngster who ignores the 
requests of his environment, making numerous mistakes and committing grave sins. His mother, Herzloyde, mourns the early death of her husband, Gahmuret (Parzival's father, whose adventures - without any model in Chrétien's Conte du Graal - are reported in books 1 and 2); she decides to educate her child far from the chivalrous world, in a solitary place, tellingly called Soltane by the German author (this is the start of book 3). But one day, young Parzival encounters a group of Arthurian knights and decides to search for King Arthur's court, leaving his dying mother behind. In Chrétien's Conte du Graal, Perceval sees his mother falling over, whereas in Wolfram's adaption Parzival does not turn back to watch her passing away. In a series of adventures, Parzival commits misconduct again, compromising innocent Jeschute (whom Wolfram presents as Erec's sister) in the eyes of her husband, Orilus, and killing his own relative, Ither, in order to deprive him of his vermilion armament when he first visits King Arthur's court. But after catching up on chivalrous education at the home of Gurnemanz, he also excels at chivalry, liberating Cundwiramurs, his future wife, from the besiegers who invade her territory (book 4). With these challenges braved, Parzival unwittingly enters the realm of the Grail for the first time (in book 5). The German narrator reports all these events while adopting Parzival's inadequate perspective and mixing it with his own observations and comments. This is also the case for the Grail ceremony the protagonist witnesses on his first visit at the Grail Castle, named Munsalvæsche. Only at a later stage, during his stay at the hermitage of his uncle, Trevrizent, (in book 9) will the mysteries of the Grail be revealed, when the hermit himself prominently adopts the role of narrator.

\section{Genealogical structures}

The genealogical structures in Wolfram's poem are of special interest, as Parzival combines the kinships of King Arthur on the patrilineal side and of the Grail on the matrilineal side (Bumke 2004, 169-176). As far as the siblings of his mother are concerned, Parzival has two aunts, Schoysiane and Repanse de schoye, the bearer of the Grail, as well as two uncles, the aforementioned Trevrizent and Anfortas, the Grail King, who is identical with the "rich fisherman" or "fisher king" (Roi Pescheor) in Chrétien's Conte du Graal. Wolfram thus enlarges the genealogical configurations of the Grail family from cousinship between Parzival and the Grail King to ancestry and succession, as, after Anfortas' regency, Parzival will become the Grail King himself. In the German poem, the maternal lineage is expanded by Anfortas' father, Frimutel, and by his grandfather, Titurel. When Parzival encounters the latter during his first visit to the Grail Castle, the narrator comments that 
the identity of this unnamed, "most handsome old man" (240:27) will be unveiled later; in order to illustrate this circuitous narrative, he employs the famous bowstring parable, which refers to a bowstring being stretched when the arrow is shot (241:1-30). At the end of the German poem, the next generation of the Grail family will also come into view: Parzival has two twin sons, Kardeiz and Loherangrin, of which only the latter is destined to become Grail King. Wolfram also mentions the marriage between Parzival's aunt Repanse de schoye and Parzival's half-brother Feirefiz, fathered by Gahmuret with the dark-skinned Oriental queen Belakane. Their son, Prester John, will assure the spread of Christendom in India, where the future kings adopt his name.

\section{The Grail ceremony and its objects}

The following description of the Grail ceremony concentrates on the objects Parzival is confronted with during his first visit to Munsalvæsche. Two types of things can be distinguished here: on the one hand are the objects Parzival comes into physical contact with; on the other are the objects he only looks at. Thus, cloak and sword as signs of sovereignty are contrasted with the lance and the Grail, the signs of the Grail mystery (for their function as signs, see Bumke 2001, 64-76). Other narrative features or items correlating with these objects will be discussed where relevant. Of special interest in this regard is the question that Parzival is expected to ask at the Grail Castle, the so-called redeeming question that could heal the suffering Grail King, Anfortas.

When Parzival arrives at Munsalvæsche, a chamberlain invests him with a cloak normally worn by Repanse de schoye, who is called the Grail Queen (228:816), whereas in Chrétien's Conte du Graal the cloak is conferred without such comment (1l. 3073-3074). In the French text, the Fisher King grants a precious sword to Perceval, a gift that Wolfram shifts to a moment after the Grail ceremony and the dinner with Anfortas and his court. In that context, as will be shown, the sword mutates from a sign of sovereignty to one of the Grail mystery.

A strange scene placed before the beginning of the Grail procession illustrates the fact that the protagonist is not yet mature enough to cope with the mysterious experience he is about to encounter. A "man deft in speech" (229:4), probably a jester, irritates Parzival, who, lacking the armour that has been taken off him, clenches his fist so furiously that blood shoots out of his nails and sprinkles his sleeves. Parzival, barely restrained from reacting violently by the attendant knights, proves to be unable to give an adequate verbal response to the jester. (229:4-22; see Weigand 1969 [1952]) This detail, not present in Chrétien, 
is equally suppressed in one of the main manuscripts of the German tradition: witness G (Munich, Staatsbibliothek, Cgm 19, mid-thirteenth century, missing 228:27-229:18). By carefully eliminating the scene, this codex, which constitutes the essential manuscript of version ${ }^{\star} \mathrm{G}$, suggests that the protagonist does not have any linguistic deficiencies.

Yet this linguistic inadequacy is also the cause of Parzival's failure while watching the Grail procession at Munsalvæsche. The unasked question is closely connected to the Grail ceremony, the sumptuousness of which Wolfram has significantly enlarged in respect to his French source. The German poet mentions numerous lights and candelabra, tables for hundreds of knights, golden dishes, and twenty-five beautiful maidens clothed in noble robes to serve in the procession.

\section{The bloody lance and the silver knives}

Before the start of the procession, a squire appears bearing a lance from whose blade blood is issuing, running down the shaft to his hand and stopping at the sleeve (231:17-22, the blood-splashed sleeve corresponds to Parzival's, mentioned in the previous scene). The presentation of the lance, carried along the four walls of the hall, evokes crying and grief. It might recall the Lance of Longinus, who thrust his spear into the flank of the crucified Christ to confirm his death, but neither Wolfram nor Chrétien hints overtly at this legend. This connection is only established in the First Continuation of Chrétien's Perceval, which was composed c. 1200. Here, the fact that the Lance of Longinus continues to bleed (which is not mentioned in the legend itself) becomes a tradition. At a later stage of the romance, a more rational explanation for the blood is given: during Parzival's stay at the hermitage, Trevrizent argues that the lance (presumably identical with the one in the Grail procession) is the poisoned weapon of a heathen who has wounded Anfortas in the testicles during a combat that he was fighting in the courtly service of a lady who was not destined by the Grail to be his lover (478:1479:17). As a remedy, the lance has to be placed into Anfortas' wound, allowing the hot poison to draw the frost from his body (489:30-490:2; 490:11-17; Parzival also refers to the scene he has watched at the Grail Castle: 492:17-22).

The glass-coloured, ice-like frost is removed from the blade with two silver knives made by the wise smith, Trebuchet (490:18-22). These knives are a misconception that Wolfram formed from the "tailleoir d'argant" [silver plate] mentioned in Chrétien's description of the Grail procession (1l. 3231, 3287). Wolfram seems to have understood the tailleoir as a derivative of the French verb taillier 
[to cut], converted it (in plural form) into two sharp silver knives and set them as cutlery for the meal at Munsalvæsche ("zwei messer snîdende als ein grât", 234:18), before then altering them in Trevrizent's speech into instruments purifying the lance. It is likely that Wolfram changed the function of the knives, as well as the concept of the lance, during his long-term composition of the text: the mysteriously bleeding lance became a bloody lance to be cleaned by the silver knives. ${ }^{3}$ The German expressions "bluotec sper" (255:11; 316:27) or "sper bluotec rôt” (490:2; 492:21) occurring in Wolfram's Parzival allow both interpretations, of a bleeding as well as of a bloody lance.

\section{The Grail and the unasked question}

While Chrétien includes the lance in the Grail procession, Wolfram introduces the latter only after the lance has been presented. The queen, Repanse de schoye, accompanied by the twenty-four maidens, conveys the Grail placed on a greencoloured cloth: "Upon a green achmardi she carried the perfection of Paradise, both root and branch; this was a thing called the Grail, earth's perfection's transcendence." (235:20-24; Stolz 2010, 189-191) During the meal, the Grail is placed on Anfortas' table, where Parzival sits down; in Chrétien's Conte du Graal, the Grail vessel passes the table during every course. Wolfram points to the fact that the Grail, similar to a magic table, offers all sorts of food and drink (238:8-239:7). Puzzled by the mysterious occurrence and remembering Gurnemanz, who has advised him not to ask too many questions, Parzival refrains from enquiring, "how it stands with this household?" (239:8-17) The wording of the unasked question might well be a reflex from Chrétien, where Perceval abstains from asking, “whom does the Grail serve?” (11. 3292-3293) Later, in the French text, Perceval's female cousin informs him that the questions of why the lance was bleeding and where the Grail procession was heading would have healed the Fisher King and restored his sovereignty (11. 3552-3570, 3583-3590). This is different in Wolfram's romance, where Parzival is expected to ask Anfortas: "hêrre, wie stêt iwer nôt?" (484:27) [“Lord, what is the nature of your distress?”], as Trevrizent later teaches his nephew during the stay at the hermitage.

Parzival's stop at his uncle's enclave - a cave situated in a rock face - on Good Friday initiates the extensive revelation of the Grail's mysteries, given first

3 Both paragraphs in book 5 and 9 are commented on in Nellmann (1994, 575-579, 694-695; 1996). 
by the narrator, and then by the hermit himself (book 9). At the start, the syncretistic history of the Grail, grounded in a blend of the three monotheistic religions, is explained. The heathen astronomer Flegetanis, son of a Jewish mother and a Muslim father, has read the name of the Grail in the stars (453:23-454:23). His visions result in a statement: "er jach, ez hiez ein dinc der grâl” (454:21) [he said that a thing was called the Grail]. This phrase resumes almost verbatim the verse occurring in the procession scene: "daz was ein dinc, daz hiez der grâl” (235:23) [this was a thing called the Grail]. Both times, the fact that "the thing" is called by the name "Grail" is emphasized. The second occurrence, following the first mention on the narrative axis, but preceding it on the historical one, combines Flegetanis' vision with a verbal utterance in which the Grail might be named for the very first time. It seems telling that a significant difference between the versions ${ }^{\star} \mathrm{D},{ }^{\star} \mathrm{m}$ and ${ }^{\star} \mathrm{G},{ }^{\star} \mathrm{T}$ (otherwise rare in book 9) arises at this point, as ${ }^{\star} \mathrm{G},{ }^{\star} \mathrm{T}$ have the variant "er jach, ez wære ein dinc der grâl" [he said that [there] was a thing [called?] the Grail] (see Stolz 2016a, 272-274). Obviously, the verb alternatives wære [[there] was] and hiez [was called] - the latter of which is also to be found in the verb sequence of verse 235:23 - highlight either the real or the linguistic existence of the Grail. The variant wære, as ${ }^{\star} \mathrm{G}$, ${ }^{\star} \mathrm{T}$ have it, represses the linguistic aspect, and might be correlated to the missing jester scene (as it occurs in manuscript $\mathrm{G}$ ), which announces Parzival's deficient linguistic behaviour at Munsalvæsche.

\section{The Grail history}

One important detail of Flegetanis' testimony is the fact that "a troop left the Grail on earth and rose high above the stars" before Christian people ("baptised fruit") had to take care of it (454:24-30). It is debatable whether this may allude to the "neutral angels" who stayed impartial after Lucifer's fall, referred to later in the text (471:15-29; 798:11-22). The "prime version of the Grail history" ("dirre âventiure gestifte”, 453:14), transmitted as a written record of Flegetanis' account (455:1), is found by Kyot, the narrator's above-mentioned authority, in Toledo, the intercultural centre of erudition and translation in medieval Spain. There he decodes the history of the Grail, composed in "heathen" (Arabian or Hebrew?) letters, supported in his understanding by the fact that he is a Christian (453:1122). Furthermore, Kyot has studied chronicles in Britain, France and Ireland - the original territories of the historical Grail legend - to look for the history of the Grail family, and discovered it in "Anschouwe" (455:2-12) [Anjou]. 
At this point, Trevrizent, engaging in a dialogue with Parzival, resumes the narration (456:5-502:30). In the course of this conversation, the "hidden tidings of the Grail" (452:30) are disclosed: Parzival learns that the Grail is a stone with the dubious name "lapsit exillis" (469:7; "lapsit exillis" in * $\mathrm{D}$ and in ${ }^{\star} \mathrm{G}$, "lapis exilis" in ${ }^{\star} \mathrm{m}$, "jaspis ex illix" in ${ }^{\star} \mathrm{T}$; for the Grail name in context with the neutral angels, see Ranke 1946, Engl. transl. 2000; for the variants of the Grail name see Nellman 2000). Its rejuvenating and life-saving powers prevent human beings from dying during the week following their having seen it (469:14-27); this is also the reason why the heavily wounded Grail King, Anfortas, lives on (480:25-29). Every Good Friday, which is also the day of Parzival's arrival at Trevrizent's hermitage, the power of the Grail, including the charms of the magic table, is renewed with a host brought by a dove from heaven (470:1-20). The Grail stone is similar to a magic bowl with appearing and vanishing inscriptions that indicate the names of boys and virgins destined for the service of the Grail (470:21-471:14). This community of guardians resembles a sacred order, and the boys, after having become knights, are called "templeise" (468:28), recalling the order of the Templars (which had been founded in 1120). Before these knights and maidens assumed guardianship of the stone under the rule of the Grail family, the "neutral angels" already alluded to by the narrator fulfilled this task (471:15-29). Thus, the legend of the Grail is projected back to the beginning of history.

Similar to the lance, the Grail evokes religious ideas without being limited to a merely Christian dimension. The "neutral angels" might have their origin in Jewish traditions. Its form of a stone and the green colour of the achmardi it is covered with could, from an Islamic perspective, also be connected with the Kaaba and the colour of the prophet Mohamed (Mertens 2003, 72). The date of Parzival's arrival at the hermitage is the Christian Good Friday, and Trevrizent uses a psalter to help Parzival regain the temporal orientation he has lost (460:25-27). Nevertheless, Wolfram reduces the apparently ecclesiastical components (chapel, priest, formal confession and Eucharist) that Chrétien uses for the scenery, and the hermit Trevrizent declares himself a layman (462:11). All of these details, including the fact that women participate in the pseudo-liturgical Grail ceremony in Munsalvæsche, point to a religious mentality of the kind practised by lay people in the twelfth century (Mertens 2003, 73; Bumke 2004, 94, 131-132). In this lay perspective, Parzival, after having omitted the redeeming question at Munsalvæsche, is brought back to religious life. Trevrizent declares that, besides the unasked question, Parzival's greatest sins are the deaths caused to his mother and to his relative, Ither (499:20-22; 501:3-5). However, when the hermit absolves his nephew from his sins, this act has no canonical character (501:17-18; 502:2526). 


\section{The Grail Sword}

The Grail Sword that Parzival receives at Munsalvæsche is also mentioned in the context of sins (501:1). Unlike in Chrétien, where Perceval is endowed with the Sword before he watches the Grail ceremony (11. 3130-3184), Wolfram's Parzival receives the Sword after the procession has ended. This deferment goes hand-in-hand with a shift of the Sword's function, which mutates from a sign of sovereignty to one of the Grail mystery. In Wolfram's romance, the Sword, once used by Anfortas in combat, is closely linked to the redeeming question. The narrator explicitly refers to it as a hint by which Parzival "was admonished to ask the question" (240:6) and he complains: “Alas that he did not ask then!” (240:3) The correlation of the sword and the unasked question is repeatedly emphasized in the poem (254:15-30; 316:21-23); and it also returns in Trevrizent's statements about Parzival's sins: "Your uncle gave you a sword, too, by which you have been granted sin, since your eloquent mouth unfortunately voiced no question there." (501:1-4) Apart from this, the Grail Sword, forged by Trebuchet like the silver knives (253:29), turns out to be an almost blind motif, ostensibly adopted from Chrétien (and from some interpolations in certain Perceval-manuscripts), appearing at intervals with some inconsistency throughout Wolfram's poem (Stolz 2016a). Its role as a guiding theme and sign used to urge Parzival - as well as the audience of the text - to ask for the secrets of the Grail and its narrative environs is supported by the fact that, soon after mentioning the Sword (fifteen days in the story, but only some lines later in the narrative: 501:11), Trevrizent discloses that the "handsome old man" is Titurel (501:19-502:3), just as was announced in the bowstring parable (241:1-30).

\section{Searching for the Grail}

Repeated references to the lance, the silver knives and the Grail Sword occur when Parzival meets his cousin, Sigune, shortly after the visit at the Grail Castle (book 5) and when his failure is proclaimed publicly by the hideous Grail messenger, Cundrie, in the presence of King Arthur and his court (book 6). In both cases, Parzival - and the audience - are partly informed about the secrets of the Grail before Trevrizent gives his more comprehensive explanations (book 9). Cundrie accuses Parzival of having committed a sin (316:23); her execration provokes Parzival to resign any joy before having seen the Grail: “That is the goal to which my thoughts chase me." (329:25-28) With this sentence, Parzival starts his intentional search for the Grail, whose realm he has entered inadvertently before. This 
is also the classical moment of crisis that occurs in the conventional scheme of Arthurian romance, for example in Chrétien's Erec and Yvain, both adapted in German by Hartmann von Aue. According to this scheme, the protagonist, after having failed in a first course of adventures, starts a second one to repair his fault, namely the neglect of the ruler's and the husband's duties in Erec and Yvain, respectively. In the Grail novel, this second course is altered, as it is split up and distributed between two protagonists: Perceval/Parzival searches for the Grail, whereas Gauvain/Gawan, the Arthurian model knight, proves himself in secular adventures of chivalry and courtly love. In the subsequent parts of the German poem (books 7-8, 10-14), the narration concentrates on Gawan, while Parzival stays in the background. Among other things, Gawan is charged with searching for the Grail by Vergulaht, who, defeated by Parzival, has himself been obligated to search for the Grail. However, Gawan's particular achievement will be the liberation of four hundred maidens and four queens, the latter being his own and King Arthur's relatives, detained by the magician Clingschor at Schastel marveile, the secular counterpart of Munsalvæsche.

Regarding Parzival's search for the Grail, it is striking that he rejects any divine guidance. After Cundrie's execration, Parzival asks, "Alas, what is god?" (332:1), which recalls a question he had addressed to his mother in Soltane, "Alas, mother, what is god?" (119:17), and which leads to his conclusion: "Now, I'll refuse Him service.” (332:7) Willingly, Parzival accepts God's enmity at this moment, an acceptance abandoned only during his stay at Trevrizent's hermitage. There, Parzival admits that his "highest anxiety concerns the Grail, thereafter the one concerning (his) own wife.” (467:26-27)

\section{The redeeming question}

The miraculous conclusion of the Grail story, which is of course not contained in Chrétien's unfinished romance, offers Parzival a second chance at Munsalvæsche. After a perilous combat with his half-brother, Feirefiz, during which the kinship of both is revealed only at the very last moment (book 15), the threads of the narrative are tied together. With the marriage of Repanse de schoye and Feirefiz, and their offspring, Prester John, future king of India, the Grail and the Grail family will unite Orient and Occident (book 16). Before this ending is achieved, though, Parzival and Feirefiz, guided by the messenger, Cundrie, return to Munsalvæsche. There, Parzival asks for the place where the Grail is kept: "Tell me where the Grail here lies." (795:21) The demand introduced by the imperative phrase "saget mir" ["tell me"], occurring in versions ${ }^{\star} \mathrm{D}$, ${ }^{\star} \mathrm{m}$, is altered into "nu zeiget mir" ["do show 
me"] in versions ${ }^{\star} \mathrm{G}$, ${ }^{\star} \mathrm{T}$. Favouring the visual aspect of display, ${ }^{\star} \mathrm{G}$, ${ }^{\star} \mathrm{T}$ again tend towards a suppression of verbal communication in this verse. Turning to the Grail and kneeling down, Parzival now pronounces the redeeming question, asking: “œheim, waz wirret dier?” (795:29) [“Uncle, what troubles you?”] This wording is somewhat different from the sentence Trevrizent suggested at the hermitage: "hêrre, wie stêt iwer nôt?” (484:27) [“Lord, what is the nature of your distress?”]. The title of "Lord" yields to the kinship term "uncle", and the polite plural form "iwer" to the more intimate pronoun "dier", which, rhyming with "stier" in the following verse (the bull as part of the Silvester legend quoted there), even evokes Wolfram's Franconian dialect (the standard form being “dir”; see Gärtner 2004, 3032). The question having been asked, Anfortas recovers immediately and Parzival is declared the new Grail King.

\section{Trevrizent's "retraction"}

Subsequently, Parzival joins his wife, Cundwiramurs, and his twin sons, Kardeiz and Loherangrin, whom he meets for the very first time after having left their mother five years previously. Before that, however, he encounters Trevrizent again, who admits "ich louc durch ableitens list/ vome grâl, wiez umb in stüende." (798:6-7) ["I have lied about the Grail and its circumstances in order to distract from it."] The whole episode (798:1-30) is highly problematic, as Trevrizent seems to retract a number of former statements, including the one concerning the "neutral angels", the first guardians of the Grail, who are now evoked as God's adversaries, condemned forever (798:11-22). In this context, Trevrizent declares: "it has ever been uncustomary that anyone, at any time, might gain the Grail by fighting.” (798:24-26) The deliberate search or even battle for the Grail seems to be forbidden to anyone. It is unclear to which utterance Trevrizent actually refers when he confesses his lie: is it to the doctrine of the "neutral angels" or to the second chance Parzival has been given to ask the redeeming question, with the latter seeming impracticable according to Trevrizent's earlier explanation (484:1-2)? (Nellmann 1994, 776; Groos 1995, 220-241) Trevrizent's unsettling "retraction" is also reflected in the manuscript transmission, as some witnesses eliminate the entire passage, whereas others try to ascribe the statement to different characters, like Feirefiz, such as the manuscripts of version * $m$ (Stolz 2004, 39-41). 


\section{The inconsistencies of the Grail: visual appear- ance, verbalization and ambiguity}

Trevrizent's announcement is also characteristic of the general "inconsistencies" and even of the "messiness" that the Grail topic entails when verbalized (Groos 1995, 241). Viewed in this light, Trevrizent, as an intra-diegetic figure, represents the difficulties the narrator runs into when trying to come to grips with the Grail matter. The lie told "durch ableitens list" (798:6) [to distract from it] might even be correlated with the narrative act itself and its deferred revelations of the Grail secrets: "ableiten" [to distract] is morphologically and semantically close to "umbe leiten" (241:16) [to redirect, or to lead astray], one of the key terms used in the bowstring parable (Herberichs 2012, 64-65). The story of the Grail turns out to be a series of delegated speech acts and references ranging from the narrator to Trevrizent, to Kyot, to the chronicles and to Flegetanis, who is said to have read the name of the Grail in the stars (Mertens 2011/2014, 281). In fact, the visual appearances of the Grail and its surroundings are central in the poem, as becomes obvious with the splendour of the Grail procession so unintelligible to Parzival during his first visit to Munsalvæsche. When the ceremony is repeated after Parzival has asked the redeeming question, the Grail remains invisible to Feirefiz, who has to wait for his burlesque baptism, which is almost exclusively motivated by his love for Repanse de schoye, before seeing the Grail. But besides the visual aspect, the verbalization of the Grail and its story is obviously fundamental from the moment it is first named by Flegetanis. On a meta-diegetic level, speaking about the Grail also refers to the audience, which has to decode the various perspectives and frequently ambiguous messages concerning the Grail following Parzival's imperfect perception of it, as reported by the narrator. In this respect, the search for the Grail and its imponderables pertains to the listeners and readers of Wolfram's Grail story, who have kept up their interest in the topic to the present day.

The diversity of different viewpoints is also manifest in the manuscript transmission, of which some examples have been given above. The continuing fascination the story held in medieval times is documented by the Rappoltsteiner Parzifal, a text in which Wolfram's Parzival was combined with German translations of the Old French Continuations of Chrétien's unfinished Conte du Graal (Mertens 2011/14, 297-300; Chen 2015; see also Taylor, supra). In this extensive conglomeration of over 60,000 lines, discrepancies are almost unavoidable. For instance, Parzival is shown healing Anfortas twice, once in vengeance (the old motif from the Celtic tradition, resumed in the French Continuation by Manessier), and once by asking the redeeming question (following Wolfram). When Parzival returns 
to Munsalvæsche for this purpose, Wolfram's text is supplemented by segments relating that King Arthur and his court escort the future Grail King. This new arrangement combining the realm of the Grail with an Arthurian entourage proves to be an "Arthurizing of the Grail." (Mertens 1998, 288-300) Thus, the Grail topic is given back to the poetic genre of Arthurian romance from which it emerged, where it was first formed by its literary founder, Chrétien de Troyes.

\section{References}

Achnitz, Wolfgang. Deutschsprachige Artusdichtung des Mittelalters. Eine Einführung. Berlin and Boston: De Gruyter, 2012.

Bumke, Joachim. Wolfram von Eschenbach. 8th edn. Sammlung Metzler 36. Stuttgart and Weimar: J.B. Metzler, 2004.

Bumke, Joachim. Die Blutstropfen im Schnee. Über Wahrnehmung und Erkenntnis im Parzival Wolframs von Eschenbach. Hermaea 94. Tübingen: Niemeyer, 2001.

Burns, E. Jane. "Quest and Questioning in the Conte du graal.” Romance Philology 41 (1988): 251-266.

Chen, Yen-Chun. Ritter, Minne und der Gral: Komplementarität und Kohärenzprobleme im "Rappoltsteiner Parzifal". Studien zur historischen Poetik 18. Heidelberg: Universitätsverlag Winter, 2015.

Chrétien de Troyes. Le Roman de Perceval ou Le Conte du Graal. Ed. Keith Busby. Tübingen: Niemeyer, 1993.

Gärtner, Kurt. "Grundlinien einer literarischen Sprachgeschichte des deutschen Mittelalters.” Sprachgeschichte. Ein Handbuch zur Geschichte der deutschen Sprache und ihrer Erforschung. 2nd edn. Ed. Werner Besch, Anne Betten, Oskar Reichmann and Stefan Sonderegger. Handbücher zur Sprach- und Kommunikationswissenschaft 2.4. 4 vols. Berlin and New York: De Gruyter, 2004. IV, 3018-3042.

Groos, Arthur. Romancing the Grail. Genre, Science, and Quest in Wolfram's Parzival. Ithaca, NY and London: Cornell University Press, 1995.

Groos, Arthur, and Norris J. Lacy, eds. Perceval/Parzival. A Casebook. New York and London: Routledge, 2002.

Haferland, Harald. “Die Geheimnisse des Grals. Wolframs Parzival als Lesemysterium?” Zeitschrift für deutsche Philologie 113 (1994): 23-51.

Hartmann, Heiko. Einführung in das Werk Wolframs von Eschenbach. Einführungen Germanistik. Darmstadt: Wissenschaftliche Buchgesellschaft, 2015.

Herberichs, Cornelia. "Erzählen von den Engeln in Wolframs Parzival. Eine poetologische Lektüre von Trevrizents Lüge.” Beiträge zur Geschichte der deutschen Sprache und Literatur 134 (2012): 39-72.

Johnson, Sidney. “Doing his own Thing: Wolfram's Grail”. A Companion to Wolfram's Parzival. Ed. Will Hasty. Studies in German Literature, Linguistics, and Culture. Rochester, NY and Woodbridge: Camden House, 1999. 77-95.

Loomis, Roger Sherman. The Grail: From Celtic Myth to Christian Symbol. Cardiff: University of Wales Press; New York: Columbia University Press, 1963. 
Mertens, Volker. "Parzival II. Der Stoff: Vorgaben und Fortschreibungen.” Wolfram von Eschenbach: Ein Handbuch. Ed. Joachim Heinzle. 2 vols. Berlin and Boston: De Gruyter, 2011; students' edition 2014. 264-307.

Mertens, Volker. "Geschichte und Geschichten um den Gral." Kulturen des Manuskriptzeitalters. Ed. Arthur Groos and Hans Jochen Schiewer. Transatlantische Studien zu Mittelalter und Früher Neuzeit 1. Göttingen: V\&R unipress, 2004. 237-258.

Mertens, Volker. Der Gral. Mythos und Literatur. Universal-Bibliothek 18261. Stuttgart: Reclam, 2003.

Mertens, Volker. Der deutsche Artusroman. Universal-Bibliothek 17609. Stuttgart: Reclam, 1998.

Nellmann, Eberhard. “Lapsit exillis? Jaspis exillix? Die Lesarten der Handschriften.” Zeitschrift für deutsche Philologie 119 (2000): 416-420.

Nellmann, Eberhard. "Produktive Missverständnisse. Wolfram als Übersetzer Chrétiens.” Wolfram-Studien XIV: Übersetzen im Mittelalter. Cambridger Kolloquium 1994. Ed. Joachim Heinzle, L. Peter Johnson and Gisela Vollmann-Profe. Berlin: Erich Schmidt, 1996. 134-148.

Nellmann, Eberhard. "Stellenkommentar.” Wolfram von Eschenbach. Parzival. Ed. Karl Lachmann. Trans. Dieter Kühn. Rev. Eberhard Nellmann. Bibliothek des Mittelalters 8,1/2; Bibliothek deutscher Klassiker 110. 2 vols. Frankfurt am Main: Deutscher Klassiker Verlag, 1994. II, 443-790.

Parzival-Project, University of Bern: <www.parzival.unibe.ch〉.

Pérennec, René. "Percevalromane." Höfischer Roman in Vers und Prosa. Ed. René Pérennec and Elisabeth Schmid. Germania Litteraria Mediaevalis Francigena 5. Berlin and New York: De Gruyter, 2010. 169-220.

Ranke, Friedrich. "Zur Symbolik des Grals bei Wolfram von Eschenbach.” Trivium 4 (1946): 20-30; English translation: "The Symbolism of the Grail in Wolfram von Eschenbach." Trans. Adelheid Thieme. The Grail: A Casebook. Ed. Dhira B. Mahoney. New York and London: Garland, 2000. 367-377.

Schirok, Bernd. " Parzival III.1. Die Handschriften und die Entwicklung des Textes." Wolfram von Eschenbach: Ein Handbuch. Ed. Joachim Heinzle. 2 vols. Berlin and Boston: De Gruyter, 2011; students' edition 2014. 308-334.

Stolz, Michael. "Dingwiederholungen in Wolframs Parzival." Dingkulturen: Verhandlungen des Materiellen in Literatur und Kunst der Vormoderne. Ed. Anna Mühlherr, Heike Sahm, Monika Schausten and Bruno Quast. Berlin and Boston: de Gruyter, 2016a. 267-293.

Stolz, Michael. "Von den Fassungen zur Eintextedition. Eine neue Leseausgabe von Wolframs Parzival." Überlieferungsgeschichte transdisziplinär. Neue Perspektiven auf ein germanistisches Forschungsparadigma. Ed. Dorothea Klein, Horst Brunner and Freimut Löser. Wissensliteratur im Mittelalter 52. Wiesbaden: Dr. Ludwig Reichert, 2016b. 353-388.

Stolz, Michael. "Chrétiens Roman de Perceval ou le Conte du Graal und Wolframs Parzival: Ihre Überlieferung und textkritische Erschließung." Wolfram-Studien XXIII: Wolframs Parzival-Roman im europäischen Kontext. Tübinger Kolloquium 2012. Ed. Klaus Ridder, Susanne Köbele and Eckart Conrad Lutz. Berlin: Erich Schmidt, 2014. 431-478.

Stolz, Michael. "A Thing Called the Grail. Oriental 'Spolia' in Wolfram's Parzival and its Manuscript Tradition." The Power of Things and the Flow of Cultural Transformations. Art and Culture between Europe and Asia. Ed. Lieselotte E. Saurma-Jeltsch and Anja Eisenbeiß. Berlin and Munich: Deutscher Kunstverlag, 2010. 188-216. 
Stolz, Michael. “Ine kan decheinen buochstap: Bedingungen vorneuzeitlichen Schreibens am Beispiel der Überlieferung von Wolframs Parzival." "Mir ekelt vor diesem tintenklecksenden Säkulum": Schreibszenen im Zeitalter der Manuskripte. Ed. Martin Stingelin, Davide Giuriato and Sandro Zanetti. Zur Genealogie des Schreibens 1. Munich: Wilhelm Fink, 2004. 22-53.

Weigand, Hermann J. “A Jester at the Grail Castle in Wolfram's Parzival.” PMLA 67 (1952): 485-510; reprinted in Wolfram's Parzival: Five Essays with an Introduction. Ed. Ursula Hoffmann. Ithaca, NY and London: Cornell University Press, 1969. 75-119.

Wolfram von Eschenbach. Parzival with Titurel and the Love-Lyrics. Trans. Cyril Edwards. Arthurian Studies 56. Woodbridge and Rochester, NY: D.S. Brewer, 2004.

Wolfram von Eschenbach. Parzival. Studienausgabe. Ed. Karl Lachmann and Bernd Schirok. Trans. Peter Knecht. 2nd edn. Berlin and New York: De Gruyter, 2003.

Wolfram von Eschenbach. Parzival. Trans. Arthur T. Hatto. London: Penguin, 1980. 
